\title{
EFFECTS OF FERTILISER AND GRAZING ON A PASTURE SPECIES MIXTURE IN HIGH COUNTRY
}

\author{
D. SCOTT and N. COVACEVICH \\ Grasslands Division, DSIR \\ Centre for Resource Management, Lincoln College
}

Abstract

The effect of 30 treatments ( 5 fertiliser rates $\times 3$ stocking densities $\times 2$ grazing methods) on an undeveloped tussock/hawkwe日d high country grassland site, sown with 12 legumes and 12 grasses and herbs, is reported.

The trial was legume dominant for at least four years. with little establishment without applied fertiliser. By the fourth spring, the most successful species were Russell lupin, red clover and alsike clover at intermediate fertility inputs $(50-250 \mathrm{~kg} / \mathrm{ha})$ and alsike and white clover under irrigation plus high superphosphate fertilissr input $(500 \mathrm{~kg} / \mathrm{ha})$.

\section{INTRODUCTION}

In a particular combination of soil moisture, temperature, soil fertility and pasture management, a single pasture species generally becomes dominant (Scott 1979). This paper describes the first four years of a long term trial in the high country, where a complex mixture of pasture species was sown and soil fertility and pasture management varied to see how species sort themselves out in different combinations.

\section{METHODS}

The experiment was at Mount John Station, Lake Tekapo. The site was dominated by mouse-ear hawkweed and fescue tussock on rolling morraine soils of the Pukaki set, and the annual rainfall is $650 \mathrm{~mm}$.

Seeding rates for twenty-three species sown as a general mixture across the trial area in the spring of 1982, using the NZAEl rotary hoe drill, are shown in Table 1. Each species, except alsike and white clover, was sown at normal seeding rates. All legumes were rhizobia coated.

Superimposed on this were thirty treatments resulting from the combinations of five fertiliser levels, three stocking rates, and two stocking methods. The design was a split-plot applied on a randomised complete block arrangement with two replications. The five fertiliser levels were the main plots; randomised within these were six sub-plots resulting from the combination of the three stocking rates and the two grazing methods. These sub-plots were fenced and measured $50 \times 8.3 \mathrm{~m}$.

The five fertiliser levels were: no applied fertiliser; $50 \mathrm{~kg} / \mathrm{halyear}$ sulphur super extra; $100 \mathrm{~kg} / \mathrm{ha} /$ year sulphur super; $250 \mathrm{kglhalyear}$ superphosphate, and 500 $\mathrm{kg} / \mathrm{ha}$ /year superphosphate plus spray irrigation. The three stocking rates were: moderate, judged to give the best regrowth and residual height for the sward; light, with $50 \%$ less; and heavy, with $50 \%$ more sheep than the moderate level. The two stocking methods were: mob stocking, with sufficient sheep to graze in four days; and sustained stock, with one, two or three sheep on the plots for as long as possible.

Grazing treatments commenced 18 months after sowing in the second autumn. Plots were not grazed in spring until early November, to give a common growth period prior to vegetation sampling. Thereafter grazing was as appropriate within each fertiliser $x$ grazing method combination. The number of sheep grazing days on each plot was recorded. 
Table 1: Principal resident species and sown species with their seeding rates used In the grazing trial.

\begin{tabular}{|c|c|c|c|}
\hline Species & Common Name & Cultivar & $\mathrm{kg} / \mathrm{ha}$ \\
\hline \multicolumn{4}{|l|}{ Residents } \\
\hline Agrostls capillaris & Browntop & & \\
\hline Anthoxanthum odoratum & Sweet vernal & & \\
\hline Festuca novae-zelandiae & Fescue tussock & & \\
\hline Pilosella officinarum & Mouse-ear hawkweed & & \\
\hline \multicolumn{4}{|l|}{ Legumes } \\
\hline Coronilla varia & Crown vetch & & 0.02 \\
\hline Lotus corniculatus & Birdsfoot trefoil & Cascade & 0.4 \\
\hline Lotus corniculatus & Birdsfoot trefoll & Maitland & 0.5 \\
\hline Lotus pedunculatus & Lotus & Maku & 2.1 \\
\hline Lotus corn. $x$ ped. & Hybrid lotus & G4712 & 2.1 \\
\hline Lupinus polyphyllus & Lupin & Russell & 2.1 \\
\hline Medicago sativa & Lucerne & Saranac & 1.8 \\
\hline Trifolium ambiguum & Caucasian clover & Prairie & 2.1 \\
\hline Trifolium hybridum & Alsike clover & Tetra & 0.4 \\
\hline Trifolium hybridum & Alsike clover & & 0.4 \\
\hline Trifollum medium & Zig-zag clover & & 1.9 \\
\hline Trifolium pratense & Tetraploid red clover & Pawera & 1.1 \\
\hline Trifolium repens & White clover & Huia & 0.3 \\
\hline \multicolumn{4}{|l|}{ Grasses } \\
\hline Agrostis capillaris & Browntop & & 0.6 \\
\hline Arrhenatherum elatuis & Tall oat grass & & 1.2 \\
\hline Bromus willdenowii & Prairie grass & Matua & 0.2 \\
\hline Bromus scorparius & & & 1.0 \\
\hline Cynosurus cristatus & Crested dogstail & & 1.3 \\
\hline Dactylis glomerata & Cocksfoot & Apanui & 5.0 \\
\hline Festuca arundinacea & Tall fescue & Roa & 4.7 \\
\hline Festuca rubra commutata & Chewings fescue & & 1.4 \\
\hline Holcus lanatus & Yorkshire fog & Massey Basyn & 1.2 \\
\hline Lolium perenne & Perennial ryegrass & Nui & 3.5 \\
\hline Lolium $x$ hybridum & Hybrid ryegrass & Ariki & 3.5 \\
\hline Pharlaris aquatica & Phalaris & Maru & 4.7 \\
\hline $\begin{array}{l}\text { Phleum pratense } \\
\text { Others }\end{array}$ & Timothy & Kaha & 1.3 \\
\hline Sanguisorba minor muricata & Sheeps burnett & & 3.0 \\
\hline
\end{tabular}

The rank order $(1=$ most; $2=2$ nd most; . .. $10=10$ th most abundant $)$ of species contribution to total pasture yield was estimated by three or four observers in each plot in late October/early November of each year. A correspondence between the ranking of a species and its \% contribution to total yield has been reported (Mannetje \& Haydock 1963, Hargreaves \& Jones 1978). This relation can be formalised mathematically, but the ratio between two ranks is also required. In this case, all ratios Rank 5/Rank 1 were recorded. Ground cover of sown legumes, sown grasses, hawkweed, bare ground, and others was also ranked visually.

\section{RESULTS \& DISCUSSION}

The stands made limited growth in the first year, reaching only two to four $\mathrm{cm}$ of height, followed by good growth in the second year. Stands were still legume dominant after five years, with sown grasses becoming apparent only at the highest fertiliser levels. Fertiliser had the greatest effect, followed by stocking rate, with only a small effect of grazing methods.

The relative ranking of the five different ground cover types is shown in Figure 1. In the second spring, mouse-ear hawkweed was still the major ground cover type at the lowest fertiliser level and was similar to legumes at all others. Sown grasses were universally the lowest ranked ground cover.

By the fourth spring sown legumes was the major ground cover type, except 

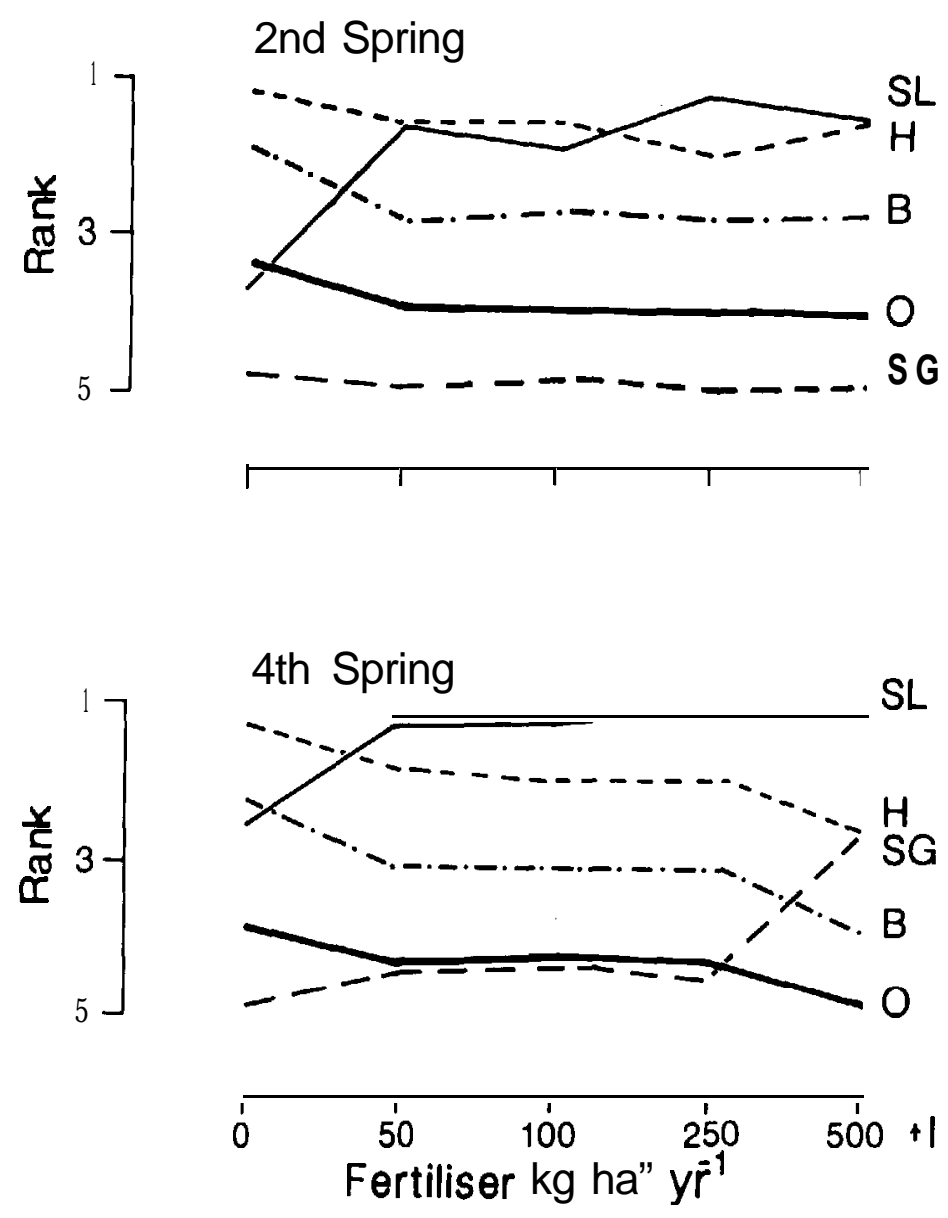

Figure 1: Relative ranking of 5 ground cover types in second spring (1983) and fourth spring (1985) in relation to 5 fertilizer levels. The cover types are: sown legumes (SL), sown grasses (SG), mouse-ear hawkweed $(H)$, bare ground $(B)$, and other resident species (0). ( 1 = species making up most of ground cover; $2=2$ nd most ...).

where no fertiliser was applied. The sown grass contribution showed a marked increase only in the $500 \mathrm{~kg} / \mathrm{ha} / \mathrm{year}$ fertiliser plus irrigation treatment.

In the second spring, the seven most important species across the trial were two of the resident species and five of the sown legumes (Figure 2). In the absence of fertiliser there was negligible contribution by any of the sown species, except Russell lupin. The residents, hawkweed and fescue tussock, were the main contributors to yield.

When fertiliser was added, the most successful of the sown species was alsike clover. Russell lupin was important at all but the highest fertiliser level. White clover, like alsike, increased with increasing fertiliser, with birdsfoot trefoil and red clover showing a lesser contribution when fertiliser was added and a less marked fertiliser response. 


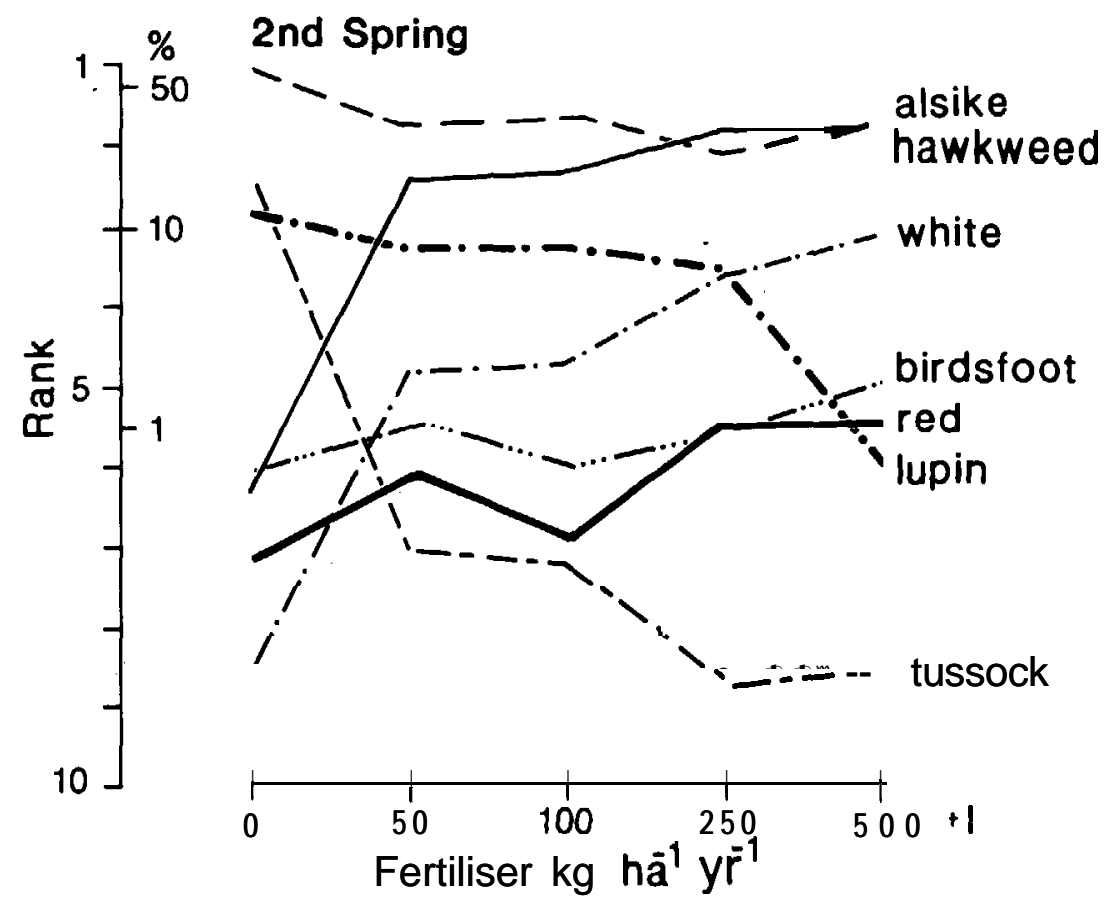

Figure 2: The effect of fertiliser on relative importance of species to pasture bulk in second spring (1983). Importance values on vertical axis given on left, by mean rank ( 1 = species contributing most to pasture yield; $2=2$ nd most important $\ldots \ldots 10=10$ th, $11=$ not in first 10 ), and on right, by estimated percentage contribution.

The relative ranking of species changed with the imposition of the grazing treatments, as is shown by the results of the fourth spring (Figure 3). Fertiliser still had the principal effect and stocking rate a lesser effect on the vegetation. Considering each of the major species in turn:

Alsike clover: Its contribution remained similar to that in the pre-grazing establishment period, with only small differences between the three grazing pressures.

Russell lupin: This was the outstanding legume of the trial, and was the highest producing (top ranked) species at four of the five fertiliser levels. It became the dominant legume in all but the highest fertiliser level. Russell lupin increased in relative importance over that in the pregrazing period. Its contribution was greater under the light stocked treatment, reflecting sheep preference for other species. However, it was the major legume in most of the light grazed treatments.

White clover: This decreased in ranking in most of the fertiliser treatments once grazing was applied after 18 months, though its contribution has continued to increase in the heavy grazed treatments with high fertiliser and irrigation.

Red clover: This has continued to increase in importance after grazing treatments started, and continued to show a very similar contribution across all the fertiliser levels and grazing intensities.

Birdsfoot trefoil: With grazing, this species decreased in relative importance at the highest fertiliser level, but maintained its ranking up to 250 the $\mathrm{kg} / \mathrm{ha} / \mathrm{year}$ 


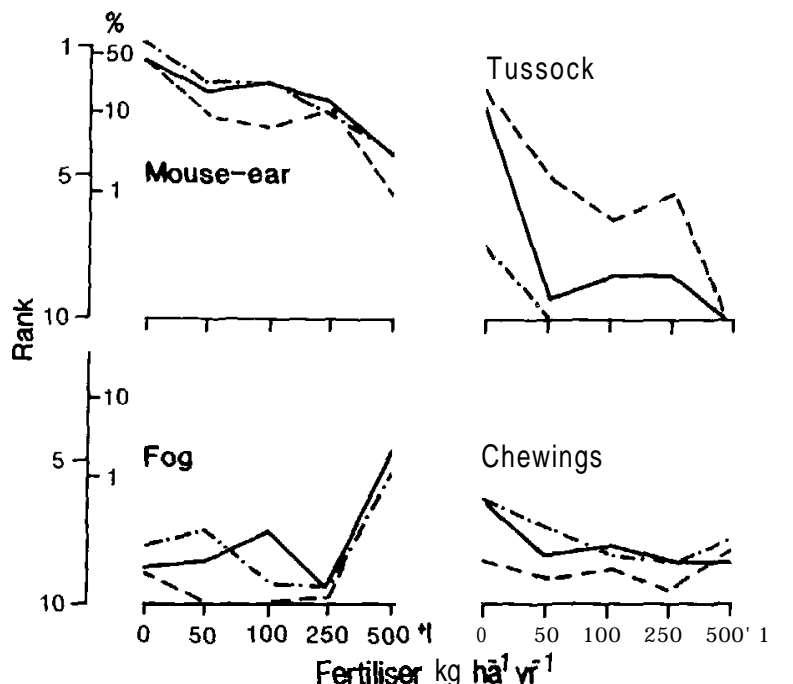

\section{Browntop}
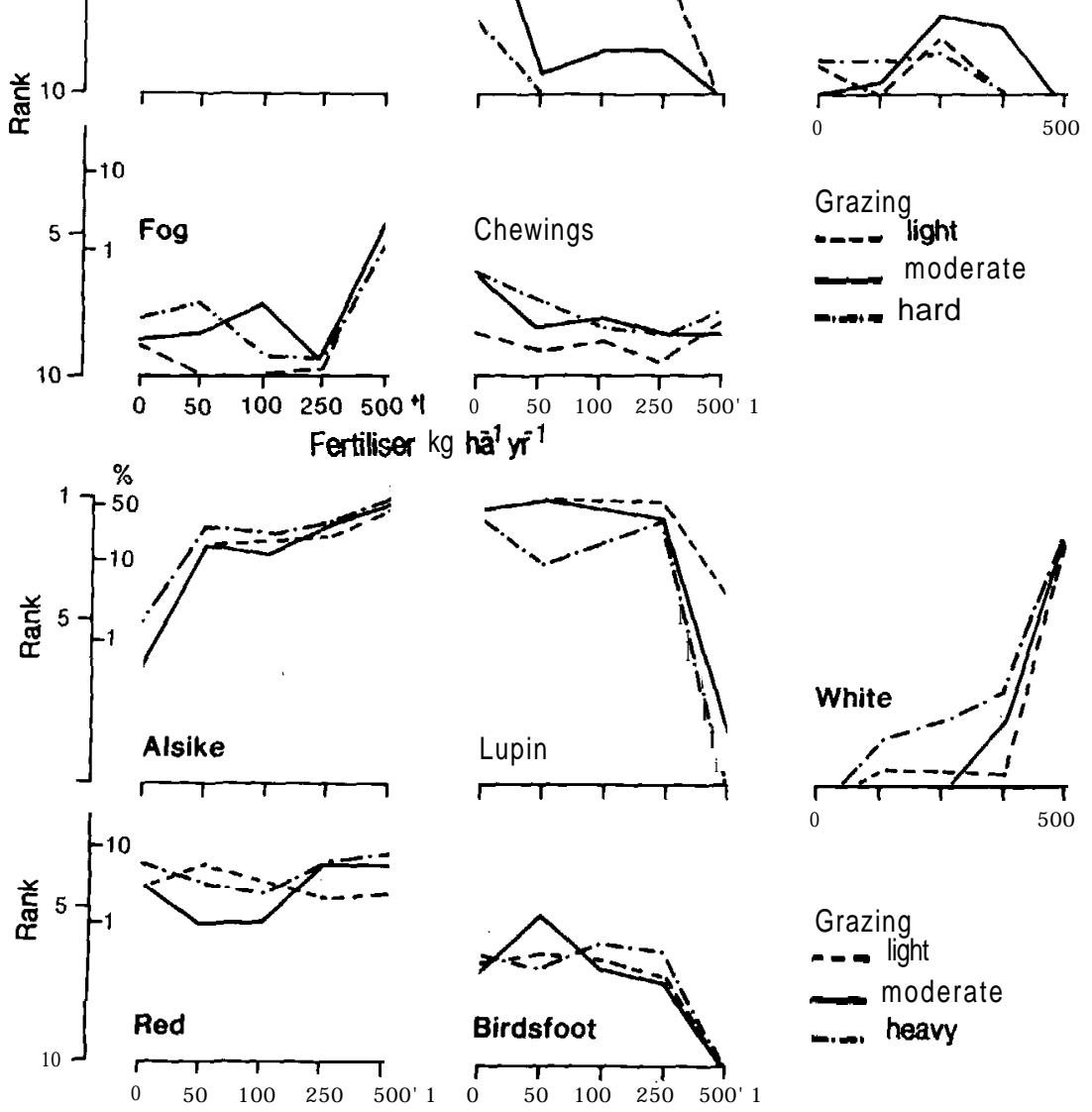

Grazing

- . light

moderate

-... heavy

Fertiliser $\mathrm{kg}$ hä $\mathbf{a}^{-1} \mathbf{y}^{1}$

Figure 3: Relative importance of species in fourth spring (1985) in relation to fertiliser rates and stocking density.

superphosphate level. There was little difference between the three grazing intensities.

Mouse-ear hawkweed: This was the major resident species at the start of the trial and under the lowest fertiliser levels during the establishment period. It decreased in importance with grazing, but was still present in the base of most swards.

Fescue tussock: This has continued to decrease both in relative terms as shown by the rankings, and in absolute terms, probably as a result of the increased grazing intensity. It has been virtually eliminated from most of the heavy grazed treatments. 
Browntop: Those present were probably the original resident plants rather than from sown seed. Browntop increased under grazing, particularly at the 100 and 250 $\mathrm{kg}$ of superphosphate ha/year and at the moderate grazing intensity.

Yorkshire fog: This was the most successful of the sown grasses. It continued to increase in importance with grazing, particularly at the two higher grazing intensities, though only at the lower fertiliser level.

Caucasian clover was the sixth most successful of the sown legumes, and increased in importance at the higher fertiliser level. Its rhizomatous spread is slow. Zigzag clover was the seventh most successful of the sown legumes, principally at moderate fertilities. Maku lotus, while initially present, has decreased. Lucerne was present only as spasmodic plants. No plants of crown vetch have been recorded.

While Yorkshire fog and chewing fescue were the most successful of the sown grass areas at all fertiliser levels, a number of the other sown grasses were appearing at the higher fertility levels in the fourth or fifth year. The order of importance after Yorkshire fog and chewing fescue is: cocksfoot, timothy, tall fescue, tall oatgrass and phalaris. Crested dogstail and short rotation ryegrass have not been seen.

Sheep's burnett was the most successful of the herb species at the establishment, but has not been recorded since.

An estimate of stock carrying capacity was obtained from the number of sheep grazing days from each treatment (Table 2). There was a low carrying capacity with no fertiliser, a similar value for the three intermediate fertiliser levels, and the high carrying capacity with high fertiliser plus irrigation. The similar stock carrying capacity at the three widely different intermediate fertiliser levels of 50, 100 and 250 $\mathrm{kg} / \mathrm{ha} / \mathrm{year}$ superphosphate is associated with the similar performance of Russell lupin at those levels and show the possibility of low fertiliser development with this legume.

Table 2: Mean stocking rates achieved in third and fourth year (sheep/ha/year= grazing days/365).

\begin{tabular}{lccccc}
\hline Fertillser treatment: & 0 & 50 & 100 & 250 & $500+$ irrigation \\
Mean stocking rate: & 1.8 & 5.8 & 5.1 & 4.8 & 13.6 \\
\hline
\end{tabular}

The trial has shown that when complex mixtures are sown, only few species survive, but that these differ between the different conditions imposed (Scott et al. 1985). The results at this high country site have illustrated the greater dominance of legumes relative to grasses in the development stage of tussock grasslands; the suitability of alsike clover; the lesser role of white clover, red clover and birdsfoot clover; for the first time under grazing that Russell lupin could have a major role as a grazing legume on lower fertility high country sites.

\section{Acknowledgements}

H. Hunter-Weston for use of land, Ravensdown for fertiliser and B.L. Sutherland, J. Robertson and L.A. Maunsell for technical assistance.

\section{References}

Jones R.M., Hargreaves J.N.G. 1979. Improvement to the dry-weight-rank method of measuring botanical composition. Grass and Forage Science 34: 181.189.

Mannetje L., Haydock K.P. 1963. The dry-weight-rank method for the botanical analysis of pasture. Journal of the British Grassland Soclety 18: 268-75.

Scott D. 1979. Potential pasture production In hill and hlgh country. Proceedings of the 1979 Hill and High Country Seminar, Lincoln College.

Scott D. Keoghan, J., Cossens G., Maunsell L., Floate M., Wills B., Douglas G. 1985. Limitations to pasture production and choice of species. In Burgess R.E., Brock J.L. (Eds). Using Herbage Cultivars, Grasslands Research and Practice Series No. 3. NZ Grassland Association. 